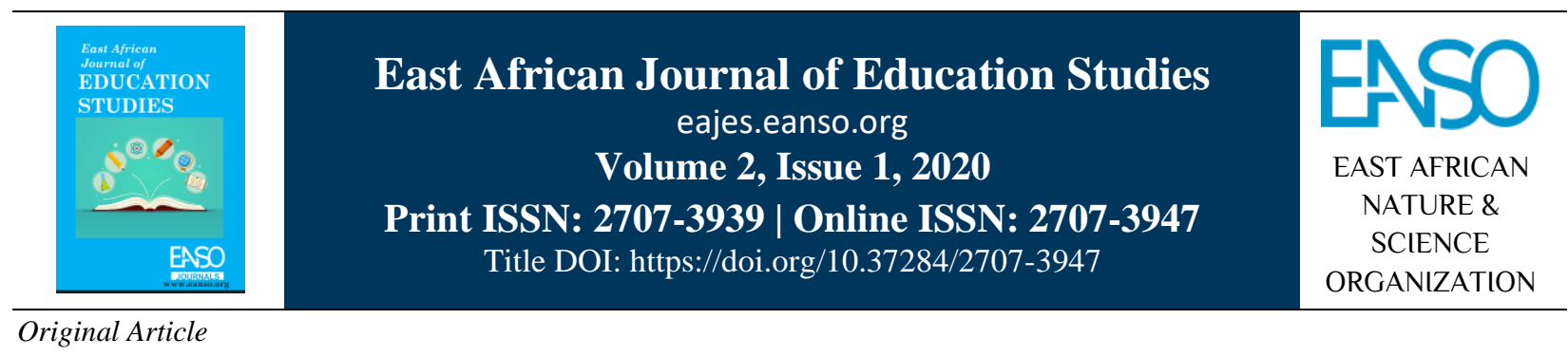

\title{
Education Opportunities and Support for Orphans and Vulnerable Children in Bagamoyo District Tanzania
}

\author{
Bertha Erasto Losioki ${ }^{1 *}$ \\ ${ }^{1}$ Department of Education, The Mwalimu Nyerere Memorial Academy, P. O. Box 9193, Dar- es Salaam-Tanzania. \\ * ORCID: https://orcid.org/0000-0001- 8874-2356; Correspondence Email: losiokibe@gmail.com.
}

Article DOI: https://doi.org/10.37284/eajes.2.1.250

\section{Date Published: ABSTRACT}

14 December 2020 Education is a fundamental and universal basic need for all, especially orphans and vulnerable children in Tanzania. Education imparts knowledge, skills, and

Keywords: competencies to individuals. This study assessed educational opportunities and the support available to orphans and vulnerable children (OVC) in Bagamoyo

Education Opportunities,

Orphans,

Vulnerable Children,

Tanzania.

District to determine socioeconomic and psychological factors that limit access to education. Data were collected using in-depth interviews, non-participant observation and documentary review. The study involved 102 orphans and vulnerable children aged between 7 and 15 years and 35 adults key informants aged 25 years and above. The findings showed that OVC had access to free primary education but had limited access to secondary education. Access to education among OVC was constrained by limited and unreliable sources of funds to meet the necessary basic needs and school requirements including food, learning materials, school uniform, and fees. The findings show further that, OVC living in extended family experience more challenges compared to those staying in orphanage homes. OVC in the family and orphanage homes experience psychological challenges such as depression, loneliness, and stress. The study recommends that community programmes aimed at assisting orphans and vulnerable children should be strengthened to enable Orphanage homes and the extended family in taking care of orphans and vulnerable children. The relevant ministry (POR-LAG) should facilitate the availability of educational resources among orphans and vulnerable children to enable them to realise their educational goals.

\section{APA CITATION}

Losioki, B. E. (2020). Education Opportunities and Support for Orphans and Vulnerable Children in Bagamoyo District Tanzania. East African Journal of Education Studies, 2(1), 187-197. https://doi.org/10.37284/eajes.2.1.250. 


\section{CHICAGO CITATION}

Losioki, Bertha Erasto. 2020. "Education Opportunities and Support for Orphans and Vulnerable Children in Bagamoyo District Tanzania”. East African Journal of Education Studies 2 (1), 187-197. https://doi.org/10.37284/eajes.2.1.250.

\section{HARVARD CITATION}

Losioki, B. E. (2020) "Education Opportunities and Support for Orphans and Vulnerable Children in Bagamoyo District Tanzania”, East African Journal of Education Studies, 2(1), pp. 187-197. doi: 10.37284/eajes.2.1.250.

\section{IEEE CITATION}

B. E. Losioki, "Education Opportunities and Support for Orphans and Vulnerable Children in Bagamoyo District Tanzania", EAJES, vol. 2, no. 1, pp. 187-197, Dec. 2020.

\section{MLA CITATION}

Losioki, Bertha Erasto. "Education Opportunities and Support for Orphans and Vulnerable Children in Bagamoyo District Tanzania". East African Journal of Education Studies, Vol. 2, no. 1, Dec. 2020, pp. 187-197, doi:10.37284/eajes.2.1.250.

\section{INTRODUCTION}

Education is among the most important needs for orphans and vulnerable children in Tanzania. Education imparts knowledge, skills, and competencies among individuals. It enables individuals to be productive and contribute to the community (UNICEF, 2009; Mulungu, 2018; Tefera \& Refu, 2019). In addition, access to education is considered important in reducing poverty and vulnerability among orphan children (UNICEF, 2009). However, education for orphans and vulnerable children is hampered by financial, social, and material resources. Lack of basic needs such as food, clothes, uniforms, medication and school fees deny orphans and vulnerable children from acquiring education (Majoni \& Majoni, 2017; Mulungu, 2018).

This study defines Orphans as pre-adolescent children with one or both parents deceased. It also refers to children who have been abandoned by one or two parents (social orphans) (Cansu, 2020). Moreover, this study considers a vulnerable child as a child whose safety, well-being, and development are threatened by lack of adequate education, psychological support, nutrition, shelter, care, and affection (World Bank, 2006).

Orphans and vulnerable children face many problems that hinder the attainment of their educational goals. They perform poorly academically compared to non-orphaned children (Tefera \& Refu, 2019). Their school attendance is poor due to a lack of resources to meet the health care and food. Therefore, being an orphan and vulnerable has a negative impact on children on school enrolment, attendance, performance, and achievement. In addition, orphans feel less empowered when their educational needs are not fulfilled. Such children are disoriented psychologically making them develop low selfesteem (Kanjanda, 2018). Despite their status as orphans and vulnerable children, they deserve a quality education.

The government of Tanzania's strive to guarantee access to education for every child through Universal Primary Education (UPE) has a positive outcome. The initiative ensures that primary education is universal and compulsory to all children (NBS \& UNICEF, 2018). Likewise, many efforts have been made to ensure that orphans and vulnerable children in Tanzania get access to education (URT, 2017). The enactment of policies and laws such as the National Child Development Policy (2008) and the Law of the Child Act No 21(2009) are among the initiatives of attaining child welfare (URT, 2012). In addition, one among the strategic objectives of the National Plan of Action for most vulnerable children is to improve access to and use of primary health care, education and early childhood care and development services (African Child Policy Forum, 2016).

Despite the improvement in the provision of basic education in the country, access to formal education among orphans and vulnerable children is still a challenge. In addition, the number of orphans and vulnerable children in Tanzania continues to increase due to urbanisation, unemployment, poverty and HIV/AIDS (Makuu, 2019). For example, at the time of the study, there were 1436 orphans and vulnerable children in Bagamoyo District, among them, 705 were males, and 731 were females (WAMATA, 2018). Furthermore, 
deprivation of education was high among the vulnerable groups. Hence, orphans and vulnerable children continued to experience educational challenges compared to non-orphans (NBS \& UNICEF, 2018).

An investigation of educational opportunities and support for orphans and vulnerable children is crucial. It provides an understanding of the available educational opportunities and support for orphans and vulnerable children and the barriers in the attainment of educational goal among these groups. It also informs key stakeholders on the plight of orphans and vulnerable children that limits them from achieving their educational goals.

The purpose of this study therefore was to assess educational opportunities and the support available for orphans and vulnerable children in attaining their educational goals. The study specifically assesses education opportunities and the support available for orphans, vulnerable children, and the factors impeding their academic achievements. This study assumes that there is limited access to education opportunities and support among orphans and vulnerable children in Bagamoyo. In addition, there are socioeconomic and psychological factors limiting academic achievements among orphans and vulnerable children in Bagamoyo District. The study's specific objectives, therefore, are first, to assess educational opportunities and the support available for orphans and vulnerable children and second to assess socioeconomic and psychological factors that limit access to education and attainment of educational goals among orphans and vulnerable children. The study, therefore, answers the following questions. First, how do the available educational opportunities and support contribute to accessing education for OVC? Second, how do socioeconomic and psychological factors limit access to education among orphans and vulnerable children?

\section{THEORETICAL FRAMEWORK}

The study is guided by Bronfenbrenner Bioecological theory as founded and advocated by Urie Bronfenbrenner. Bronfenbrenner argues that child development emerges from the interaction of individual and the environment in which an individual spends time and the relations with others in various system levels. Thus, child development is influenced by the interconnected layers within the environment (Bronfenbrenner, 2001). Orphans as individuals are part of the various systems of society. These systems include family, school, and community. It also includes institutional systems such as social, economic, education, legal and political systems. Issues experienced in each level of the system tend to affect orphans' family lives, school performance, as well as community interaction. For example, the family can directly influence a child through the socialisation process within the microsystem. Likewise, the school and peer represent the mesosystem in which the child's interactions and the interrelationship between school and home influence child development. In addition, teachers and caregivers' interaction with child education and behaviour can also influence cognitive and emotional development (Bronfenbrenner \& Morris, 2006).

This study used Bronfenbrenner Bioecological theory to assess educational opportunities and support available for orphans and vulnerable children in systems such as family, orphanage centres, and the community. It also guided the study in examining socio-economic and psychological factors that limited the attainment of educational goals among orphans and vulnerable children.

\section{METHODOLOGY}

The study was conducted in Zinga and Dunda Wards in Bagamoyo District. The population in Bagamoyo District is 311,740 where males are 154,198 and females are 157, 542. The average household size is 4.4. The population in Zinga ward, which is in a rural area, is 11,189 where males are 5600 and females are 5589. The average household size is 4.0 (URT, 2013). Dunda Ward is in the urban area and which has a population of 14,559 where males are 7,091 and females are 7,091 . The average household size is 4.2 (URT, 2012). This study employed a qualitative research design. The study target primary and secondary school OVC in orphanage homes and those living in extended families. The study involved 102 orphans and vulnerable children aged between 7-15 years and 35 adult key informants aged 25 years and above. The respondents were selected through purposeful sampling from two orphanage homes; 
one in the rural and the other in the urban area. OVC living in the extended family were selected from 16 households that were also selected purposively from both urban and rural areas ( 8 households in rural and urban respectively). In-depth interviews, non-participant observation, and documentary review methods were used to collect data. The total sample size was 137 respondents. Data were sorted and coded based on themes and analysed through content analysis.

\section{FINDINGS AND DISCUSSION}

\section{Characteristics of the Respondents}

The demographic characteristics of the respondents are presented according to sex, age, and education level, as detailed in Table 1 .

Table 1: Demographic Characteristics of respondents $(n=137)$

\begin{tabular}{|c|c|c|c|c|c|}
\hline \multirow[t]{2}{*}{ Characteristics of Respondents } & & \multicolumn{4}{|c|}{ Sex } \\
\hline & & M & $\mathbf{F}$ & $\mathbf{n}$ & $\%$ \\
\hline OVC in Orphanage homes & & 19 & 16 & 35 & 25.5 \\
\hline OVC in extended family & & 28 & 39 & 67 & 49 \\
\hline Caregivers/ step parents & & 5 & 14 & 19 & 13.9 \\
\hline Heads of $\mathrm{OH} /$ Coordinators & & 2 & 2 & 4 & 2.9 \\
\hline Government Officials/social workers \& Teachers & & 6 & 6 & 12 & 8.7 \\
\hline \multicolumn{6}{|l|}{ Age group } \\
\hline & $7-10$ years & 28 & 35 & 63 & 46 \\
\hline & $11-15$ years & 19 & 20 & 39 & 28.5 \\
\hline & $25-55$ years & 8 & 17 & 35 & 25.5 \\
\hline \multicolumn{6}{|l|}{ Education Level } \\
\hline \multirow[t]{2}{*}{ OVC children } & Primary school & 28 & 35 & 63 & 46 \\
\hline & Secondary school & 19 & 20 & 39 & 28.5 \\
\hline Caregivers & Secondary School & 5 & 14 & 19 & 13.9 \\
\hline Heads of $\mathrm{OH} /$ Coordinators & Diploma and above & 2 & 2 & 4 & 2.9 \\
\hline Government Officials/social workers \&Teachers & Diploma and above & 6 & 6 & 12 & 8.7 \\
\hline
\end{tabular}

The findings in Table 1 show that about a half $(46 \%)$ of orphans and vulnerable children were in primary school while only about a third $(28.5 \%)$ were in secondary school education. In addition, about a half $(49 \%)$ of orphans and vulnerable children were from extended family compared to only a quarter $(25.5 \%)$ who were in orphanage homes. This has implications in educational support provided to OVC. The literature shows that Orphan children's families have limited finances and are in extreme poverty (World Bank, 2006, World Bank, 2019). This suggests that orphans and vulnerable children living in extended family experience problems in the attainment of their education. These are, therefore, likely to perform poorly when compared to other children.
Regarding the age, about a half $(46 \%)$ of OVC were between $7-10$ years while about one third $(28.5 \%)$ of the OVC were aged between 11 and 15 years. The findings show further that less than twenty per cent (13.9) were caregivers and stepparents and had secondary education. Other key informants were represented by less than ten per cent including Heads/Coordinators of Orphanage Homes as well as Government Officials/social workers and Teachers. These respondents provided relevant information regarding educational opportunities and challenges facing orphans and vulnerable children. 
The Status of Orphans and Vulnerable Children in the Study Areas

The findings obtained through documentary reviews show that the number of orphans is slightly higher in a rural area compared to the urban area. Table 2 shows the status of orphans and vulnerable children in Dunda and Zinga Wards.

Table 2: The status of Orphans and Vulnerable Children in Dunda and Zinga Wards

\begin{tabular}{lll|ll|ll}
\hline \multirow{2}{*}{ WARD } & \multicolumn{3}{l}{ Number of Orphans and Vulnerable Children } & \multicolumn{2}{l}{ Total } \\
& Male & & Female & \% & n & \% \\
\hline Dunda & 110 & 23.7 & 115 & 24.8 & 225 & 48.5 \\
Zinga & 104 & 22.4 & 135 & 29.1 & 239 & 51.5 \\
Total & $\mathbf{2 1 4}$ & $\mathbf{4 6 . 1}$ & $\mathbf{2 5 0}$ & $\mathbf{5 3 . 9}$ & $\mathbf{4 6 4}$ & $\mathbf{1 0 0}$ \\
\hline
\end{tabular}

Source: Compiled from WAMATA Report, 2018

The information in Table 2 shows that the number of orphans and vulnerable children is slightly higher $(51.5 \%)$ in Zinga ward which is in a rural area compared to Dunda ward (48.5\%) which is in the urban area. Furthermore, the number of female orphans and vulnerable children is slightly higher (53.9\%) compared to the number of male orphans and vulnerable children (46.1\%). These findings imply that females are more vulnerable compared to males. This has implications in access to education and attainment of educational goals among female orphans and children.

Education Opportunities and Support Available for Orphans and Vulnerable Children

The study intended to find out educational opportunities available for orphans and vulnerable children. Table 3 summarises the results.

Table 3: Educational Opportunities and support for Orphans and vulnerable Children

\begin{tabular}{|c|c|c|c|c|}
\hline Data Items & Codes & Category & Sub-themes & Themes \\
\hline $\begin{array}{l}\checkmark \text { The orphanage Centre } \\
\text { assists us to attend both } \\
\text { primary and secondary } \\
\text { school. } \\
\checkmark \text { Before joining the } \\
\text { orphanage home, we could } \\
\text { hardly attend school and have } \\
\text { a close follow up for our } \\
\text { schooling. }\end{array}$ & $\begin{array}{l}\text { Primary education } \\
\text { Secondary education } \\
\text { Education } \\
\text { Opportunity }\end{array}$ & $\begin{array}{l}\text { Basic } \\
\text { education } \\
\text { opportunity }\end{array}$ & $\begin{array}{l}\text { Provision of } \\
\text { primary and } \\
\text { secondary } \\
\text { education } \\
\text { among orphans }\end{array}$ & $\begin{array}{l}\text { Education } \\
\text { opportunities } \\
\text { for orphans }\end{array}$ \\
\hline $\begin{array}{l}\checkmark \text { We get support from } \\
\text { various sources; however, it } \\
\text { is not enough to meet all } \\
\text { requirements for children. }\end{array}$ & $\begin{array}{l}\text { Donor support } \\
\text { Government support } \\
\text { Family support }\end{array}$ & $\begin{array}{l}\text { Education } \\
\text { support }\end{array}$ & $\begin{array}{l}\text { Provision of } \\
\text { social, } \\
\text { economic, and } \\
\text { moral support }\end{array}$ & $\begin{array}{l}\text { Educational } \\
\text { support for } \\
\text { orphans }\end{array}$ \\
\hline $\begin{array}{l}\checkmark \text { Various people visit and } \\
\checkmark \text { Assist us. }\end{array}$ & $\begin{array}{l}\text { Personal/community } \\
\text { support }\end{array}$ & & & \\
\hline
\end{tabular}




\section{Educational Opportunities for Orphans and Vulnerable Children}

The findings in Table 3 show that educational opportunities available include primary school education, which is provided by the government free for every child. Hence, orphans and vulnerable children had access to education like other children. Another educational opportunity available for orphans and vulnerable children was secondary schools education. However, only a few orphans and vulnerable children had access to secondary education. The reason for the lack of access is the affordability of school fees and other school requirements.

The Centre coordinator at Dunda had this to say:

"All children in our centre are studying in government schools due to affordability of fees in secondary school and free primary education...." (August 2020).

It was further found that despite the provision of primary and secondary school education, there was a good arrangement made by the government through the district council in identifying and providing support to children who were in need of educational support in other education levels. A social worker aged 42 at Dunda had this to say:

"Orphans and vulnerable children who continue with post-secondary education get support from the government and other different sponsors who pay for their fees and other basic needs. For example, there are organisations that provide educational support to OVC including CAMFED and ASANTE SANA which support education provision up to University level. WAMATA is also involved in supporting OVC to attain their dreams..." (August 2020).

Hence, there were also opportunities for postsecondary education particularly for orphans who performed well in secondary education. It was reported that there were opportunities available for attending certificate, diploma, and University degree.

Therefore, the findings suggest that there was educational support provided to orphans and vulnerable children. In addition, there was cooperation between the government, non - state actors, and the family to ensure that orphans and vulnerable children like any other children get access to education.

\section{Grants and Scholarships available to Support Orphans and Vulnerable Children}

\section{Support from the Government}

The findings show that the government of Tanzania played a major role in financing education of the Orphans and vulnerable children in primary schools. Primary education is free and school fees in secondary schools are low and affordable compared to those in private school. The social worker at Dunda reported,

Majority of Orphans and vulnerable children are in government primary and secondary schools. Primary school education is free for all children. School fees for government secondary school are affordable for parents and guardians (August 2020).

The United Republic of Tanzania (2020) show that the government provides capitation grants to run government primary and secondary schools. For example, capitation grants for fee-free basic education in primary school for Bagamoyo District in 2019/2020 was 153, 095,608 TZS. Moreover, capitation grants for secondary schools were $73,132,768 \mathrm{TZS}$. This shows that the government is committed to the provision of basic education.

\section{Support from Non-state Actors}

The findings show that orphans and vulnerable children in some orphanage homes got educational support from non-state actors at both international and national levels. Through this kind of support, orphanage homes got financial support to run the centres, including the provision of education, school materials, and basics needs for children.

Furthermore, the study found that non - state actors also supported the provision of health care services and administration costs. For example, all children in the orphanages home visited had health insurance. The Orphanage centre Coordinator in Zinga had this to say: 
We have managed to provide health insurance to all children in the centre... We got the funds from our internal sources, donor funds, and support from well-wishers... (August 2020).

The centres also provided all the necessary requirements for OVC schooling including uniforms, school fees, learning materials such as pens and pencils, books, and exercise books. The Orphanage Centre coordinator in Dunda had this to say:

"We have budget for all the necessary requirement... Including food, school fees, medical expenses, and salaries for all workers. We receive funds monthly... The source of fund for our centre is from donors. However, we take a limited number of OVC based on the budget..." (August 2020).

Thus, there were Orphanage homes that got support in terms of funds that enabled them to run the centres and meet the necessary needs for OVC and caregivers. These orphanage homes managed to afford all school requirements for children. However, the budget was inadequate suggesting that not all OVC had access to educational support.

\section{Family Support}

The findings show that the extended family played a key role in supporting OVC in terms of food, school requirements, and medication. However, it was found that the services and support provided by the families were inadequate. An orphan boy aged 13 years in Dunda had this to say:

"I was living with my mother but since she passed away I started to live with my grandmother. I can hardly get the school requirement and attend school" (August 2020).

The findings show that due to financial constraints, family members can hardly meet the school requirements and other educational materials for OVC. Kibachio and Mutie (2018) also show that orphans were not schooling as they failed to pay school fees due to poverty. They dropped out of school as they lacked school fees. In addition, the World Bank (2019) revealed that even when education is free, the cost of school supplies and medical facilities make education expensive and therefore many poor rural families still cannot afford.

\section{Community Support}

The findings show that there was educational support from well-wishers from the community. These included visitors from within and outside the country and community members who volunteered to help children and pay for school requirements, basic needs, and health care services. The orphanage manager at Zinga had this to say:

We have few income generation activities that assist us to run the centre... It is not adequate to meet all the requirements. We also receive support from well-wishers... We do not have specific sources of funds (August 2020).

The findings suggest that support from community members (well-wishers) played a crucial role in assisting orphans and vulnerable children particularly in orphanage homes that did not have specific and reliable sources of funds to run the centres.

\section{Psychosocial support available for Orphans and Vulnerable Children}

The findings show that orphans were provided with social, emotional, and mental health support in the extended families and orphanage homes. Psychosocial support intends to meet the wellbeing of orphans and vulnerable children. The findings show further that OVC in orphanage homes was provided with family care support as they live with stepparents and were taken care of like in a normal family. The intention of having stepparents was to guide and assist children to handle psychological problems such as depression, anxiety, and stress. The Orphanage Centre coordinator in Dunda had this to say:

"Step parents (mother) help children to feel comfortable psychologically. In addition, they guide children in acquiring accepted cultural values and behaviour that help them to fit in their community" (August 2020).

The findings show that there were efforts in ensuring that orphans and vulnerable children get the assistance of coping with trauma after the loss 
of their parents. Psychosocial support helps to deal with trauma-related to their parents' death and anxiety (Lindsjo, 2018). It also helps to avoid withdrawal from social activities associated with their past experiences.

\section{Barriers to Education Access among Orphans and Vulnerable Children}

The study identified socioeconomic and psychological factors that limited access to education among orphans and vulnerable children. Table 4 gives the details.

Table 4: Barriers to Education Access among Orphans and Vulnerable Children

\begin{tabular}{|c|c|c|c|}
\hline Data Items & Codes & Category & Themes \\
\hline $\begin{array}{l}\text { There are problems affecting schooling, } \\
\text { e.g. inability to pay fees on time, } \\
\text { inadequate learning materials, lack of } \\
\text { school uniform and school requirements. }\end{array}$ & $\begin{array}{l}\text { Inability to pay fees } \\
\text { Lack of school } \\
\text { uniform and school } \\
\text { requirements. }\end{array}$ & $\begin{array}{l}\text { Social- } \\
\text { economic } \\
\text { factors }\end{array}$ & $\begin{array}{l}\text { Educational } \\
\text { challenges } \\
\text { facing OVC }\end{array}$ \\
\hline $\begin{array}{l}\text { I sometimes experience stress and feel } \\
\text { lonely. }\end{array}$ & $\begin{array}{l}\text { Depression } \\
\text { Stress } \\
\text { Loneliness }\end{array}$ & $\begin{array}{l}\text { Psychosocial } \\
\text { factors }\end{array}$ & $\begin{array}{l}\text { Psychological } \\
\text { factors } \\
\text { affecting } \\
\text { education } \\
\text { among OVC }\end{array}$ \\
\hline
\end{tabular}

\section{Social- Economic Barriers}

The findings show that the provision of education for OVC is constrained with the scarcity of funds. For example, there were orphanages homes that did not have specific and reliable sources of funds to meet the necessary needs for OVC, including food, learning materials, school uniform, and fees. Sometimes secondary school children did not attend school due to lack of school fees. These factors were experienced due to the lack of reliable sources of funds. The Orphanage home coordinator at Zinga had this to say:

It sometimes happens that we experience financial constraints and we fail to meet Children's school requirements on time, especially payment of school fees when the schools open... This limit student's attendance to school... (August 2020).

The findings show further that OVC attendance to school is sometimes affected by the inability to pay for school fees in time. Other studies also found that orphans tend to postpone training due to socio and economic challenges (Meli, 2015). In addition, despite living with guardians or living in orphanage centres, orphans and vulnerable children experience various challenges that limit the realisation of their dreams (Kanjanda, 2018).
The findings also show that OVC living in the extended family experience more challenges compared to those staying in orphanage homes. Family members explained the difficulties that they face when taking care of orphans and vulnerable children as reported by a woman aged 58 years:

I have two grandchildren in primary school...It is difficult to take care of them. I am not well financially... I sometimes fail to buy learning materials such as exercise books, pen, school bags and school uniforms (August 2020).

Other studies revealed that OVC living in extended families experience many problems due to poverty. For example, Kazeem and Jensen (2017) found that extended family networks might not always be proper in meeting the educational needs of orphans. A study conducted in Makete also shows that school-going orphans lack basic needs such as food, clothes, and medication (Lindsjo, 2018).

\section{Psychological Barriers}

The findings show that OVC tends to feel isolated and unhappy compared to other students. This affects their concentration in class. A teacher aged 41 years at Dunda had this to say:

When in school orphans and vulnerable children show vividly that they miss something, 
they feel lonely, and others fall sick several times this affect their schooling... (August 2020).

The findings revealed that $\mathrm{OVC}$ experience psychological challenges such as depression, loneliness as well as stress. These affect their mental health and concentration in their studies, participation in classrooms activities, and school attendance. For example, their school attendance is not frequent with others dropping out of school due to such challenges. In addition, these children also frequently encounter health problems. This was due to their family backgrounds and the environment in which they were raised. Other studies (e.g., Olanrewaju et al., 2015; Pillay, 2018) also found that Orphan children had poor school attendance rates compared to non - orphaned children. In addition, mental and physical well- being issues are more common with OVC and thus affecting their academic performance.

The findings show further that OVC performed poorly when compared to other children. A male teacher aged 52 years at Dunda had this to say:

Their performance is average for most of them and others perform poorly... Their environment affects their schooling... Even their attendance is poor and others tend to drop out of school (August 2020)

The findings imply that inadequate attendance and participation in school activities affect students' performance in school. A study conducted in Zimbabwe also shows that Orphans performance in school is poor due to the challenges they are facing in their lives (Oyedele, Chikwature \& Manyange, 2016). A study by Majoni and Majoni (2017) also shows that orphaned children perform poorly academically and that, their education was negatively affected by financial, social, and material resources

\section{CONCLUSIONS AND RECOMMENDATIONS}

The study results have shown that OVC had access to free primary education; however, their access to secondary education was limited. The provision of education for OVC was constrained by limited and unreliable sources of funds to meet the basic needs including learning materials, school uniforms, and fees. The findings showed that OVC living in extended families experience more challenges compared to those staying in orphanage homes. However, they all experienced psychological challenges such as depression, loneliness, and stress. This affected their concentration in their studies. It also affected their effective participation in classrooms activities and school attendance.

Community programmes that target in assisting orphans and vulnerable children should be strengthened in order to enable Orphanage homes and the extended families take care of orphans and vulnerable children. In addition, the relevant ministry (POR-LAG) should facilitate the availability of educational resources among orphans and vulnerable children in order to assist them in realising their educational goals.

\section{REFERENCES}

African Child Policy Forum. (2016). Implementing Child Rights in Tanzania. What is Working Well, What is not? Background paper to the African Report on Child Well-being. Addis Ababa: The African Child Policy Forum.

Bronfenbrenner, U (2001). The Bio Ecological Theory of Human Development, In Smelser, N. J. \& Baltes, P. B (Eds), International Encyclopedia of the Social and Behavioural Sciences (pp.6963-6970). Oxford: Elsevier.

Bronfenbrenner, U. \& Morris, P. A. (2006). The Bio Ecological Model of human development. In Lerner, R. M. \& Damon, W. (Eds), Handbook of Child Psychology: Theoretical Models of Human Development (pp. 793-828). New York: John Wiley \& Sons, Inc.

Cansu, N. (2020). Orphan Report 2020. INSAMER. Retrieved from https://insamer.com/rsm/icerik/dosya/dosya_29 28.pdf

Kanjanda, O. (2018). The educational challenges faced by the orphans in Manicaland province, Zimbabwe. European Journal of Social Sciences Studies, 2(2), 62-85. 
Kazeem, A., \& Jensen, L. (2017). Orphan status, school attendance, and their relationship to household head in Nigeria. Demographic Research, 36, 659-690.

Kibachio, D. N., \& Mutie, P. M. (2018). Challenges Affecting Orphans and Vulnerable Children (OVC) in Embu County. International Journal of Sociology, 1(1), 18-36.

Lindsjö, K. (2018). The financial burden of a feefree primary education on rural livelihoods-a case study from rural Iringa Region, Tanzania. Development Studies Research, 5(1), 26-36.

Majoni, A., \& Majoni, C. (2017). Assessing factors contributing to poor academic performance of orphaned children in primary schools. European Journal of Education Studies, 3 (6), 785-795.

Makuu, M. J. (2019). Situation Analysis of Orphans and Vulnerable Children in Existing Alternative Care Systems in Dar es Salaam, Tanzania. Social Work \& Society, 17(1), 1-18.

Meli, B. M. (2015). Provision of Vocational Skills Education to Orphans: Lessons from Orphanage Centres in Dar es Salaam City, Tanzania. Journal of Education and Practice, 6(15), 6575 .

Mulungu, C. A. (2018). Challenges Facing Orphans in Acquisition of Secondary Schools Education in Makete District. Ruaha Journal of Arts and Social Sciences, 4, 39-51.

National Bureau of Statistics (NBS) and the United Nations Children's Fund (UNICEF). (2018). Child Poverty in Tanzania based on 2014/2015. National Panel Survey - Summary Report. Dar es Salaam: NBS and UNICEF.

Olanrewaju, A. D., Jeffery, C., Crossland, N., \& Valadez, J. J. (2015). Access to education for orphans and vulnerable children in Uganda: a multi-district, cross-sectional study using lot quality assurance sampling from 2011 to 2013. PloS one, 10(7), e0132905.

Oyedele, V., Chikwature, W., \& Manyange, P. (2016). Challenges Facing Orphaned Students and the Effects on Academic Performance in OLevel Commerce at Samaringa Cluster
Secondary Schools. International Journal of Academic Research and Reflection, 4(3), 37-45.

Pillay, J. (2018). Early education of orphans and vulnerable children: A crucial aspect of social justice and African development. Koers, 83(1), $1-12$.

Tefera, B. S., \& Refu, A. T. (2019). Orphan Children's School Performance, Hindering Challenges and the Role of the School (In the Case of Some Selected Primary Schools in Iluababor Zone, Ethiopia). International Journal of Multicultural and Multireligious Understanding, 6(3), 314-330.

UNICEF. (2009). Promoting Quality Education for Orphans and Vulnerable Children: a sourcebook of programmer experiences in eastern and southern Africa. New York: UNICEF

United Republic of Tanzania (URT). (2012). Framework for implementation of long-term perspective plan, five-year development plan and annual plans. Dar es Salaam: Ministry of Community Development, Gender and Children.

United Republic of Tanzania (URT). (2013). Population and Housing Census. National Bureau of Statistics and Ministry of Finance.

United Republic of Tanzania (URT). (2017). PrePrimary, Primary, Adult and Non- Formal Education Statistics in Brief. Dodoma: President's Office- Regional Administration and Local Government.

United Republic of Tanzania (URT). (2020). Summary Primary and Secondary Schools Capitation Grants 2019-2020. Tamisemi.go.tz

WAMATA. (2018). Bagamoyo District Council oVC Data. Wazazi na Malezi Tanzania. WAMATA

World Bank. (2006). Ensuring Education Access for Orphans and Vulnerable Children. A Planner's Hand Book. $2^{\text {nd }}$ Edition. Washington: UNICEF 
East African Journal of Education Studies, Volume 2, Issue 1, 2020

Article DOI: https://doi.org/10.37284/eajes.2.1.250

World Bank. (2019). World Development Report 2019. The Changing Nature of Work. Washington: World Bank. 